\title{
Handling The Juvenile Delinquency Caused by Consuming Alcohol
}

\begin{abstract}
Ali Ashadi ${ }^{1}$ and Amin Purnawan ${ }^{2}$
Abstract. The problem in this research are: 1) The factors that affect juvenile delinquency caused by consuming alcohol 2) The handling of juvenile delinquency caused by consuming alcohol. The purpose of this study were 1) To identify and explainfactors that affect juvenile delinquency caused by consuming alcohol. 2) To identify and explain the handling of juvenile delinquency caused by consuming alcohol.

Based on the results of the study concluded that: 1) The factors that influence the habit of drinking in teenagers is a curiosity, social environment, family environment, the influence of alcohol sales freely, and as a result of the rule of law (sanctions and fines lightweight). 2) Disaster of drinking habits in teenagers by the police is divided into two stages: a preventive and repressive. Namely preventive measures, early efforts made by the police to prevent all crimes include socialization, raid the alcohol, and Binamitra (one of strategy in police), while the repressive efforts, action to suppress and restrain delinquency or impede the onset of delinquency greater events include foreclosure, arrest, legal action.

Keywords : Handling; Delinquency; Alcohol.
\end{abstract}

\section{Introduction}

Teenagers are the future generation who have a great responsibility in the future of a nation's progress. Faced with the progress of time or globalization, teenagers need to be prepared early, both mentally and spiritually. Adolescence is a period of transition from childhood into young people mature, usually lasts between 12-13 years of age until the age of 19-20 years. Adolescence is regarded as a dangerous period because during that period, a person leaving the stage of life of children towards the next stage, maturity stage. ${ }^{3}$ This period is perceived as a crisis because of the lack of grip, while his personality is undergoing formation. Adolescence is considered as a preparation for adulthood with all changes such as physical changes, social relations, increased capabilities and skills, as well as identity formation. Teens no longer a child and not an adult. Adolescents begin to try to act and behave like an adult, such as drinking alcohol.

Teenagers are the most influential generation in realizing the ideals of a nation, as the next generation of a nation and a generation that expected by a nation can change the state of the nation into a better nation. ${ }^{4}$ The state of today's youth is very alarming, it can be seen from the condition of today's teenagers who tend to be more free and rarely due attention to moral values embodied in every action they lakukan.Remaja

\footnotetext{
${ }^{1}$ Student of Masters (S2) of Law Faculty of Law Unissula Semarang e-mail : aliakudus@gmail.com

${ }^{2}$ Lecturer of Faculty of Law UNISSULA Semarang

${ }^{3}$ Desmita. 2010, Psikologi Perkembangan. PT Remaja Rosdakarya, Bandung, p. 190

${ }^{4}$ Hassan Shadily, 1993, Sosiologi Untuk Masyarakat Indonesia, PT Rinerka Cipta, Jakarta, p. 163
} 
have properties that tend to be more aggressive, emotional setabil not, and can not resist the urge appetite.

Adolescent moral deterioration is influenced by several things and the most dominant influence on adolescent moral change is a social factor. And many teenagers in Indonesian wrong in choosing the association so that they fall into promiscuity among others consume illegal drugs (narcotics), drinking, fights between students, and free sex and so forth. ${ }^{5}$

Teens in essence is struggling to find himself, if faced with external circumstances or less harmonious environment full of contradictions and instability, it is easy then will they fall on the inner misery, life is full of anxiety, confusion and uncertainty. Things like this have led Indonesian teenagers fall on behavior disorders that bring harm to itself either now or in the future. ${ }^{6}$

Juvenile delinquency is a problem that is actually very interesting to talk about. In recent years, it has negative consequences arise very worried about the undoing of the teens themselves and society in general. Some forms of delinquency often do a teenager such as smoking, drinking, brawling, stealing, drugs, fights, and many other forms of juvenile delinquency.

And the impact on the nature or actions that could be called juvenile delinquency. Juvenile delinquency is a behavior disorder, acts or actions that are asossial adolescent antisocial even violating of social norms, religious, and legal provisions prevailing in society.

Looking at the various facts that occurred today, it is due to too away their freedom in the mix, the main factor is the lack of understanding of the problem of today's society of the limits of relationships between men and women. Besides, it is supported by the modernization that has been globalized and the weakness of our faith fort resulted in an influx of foreign culture without a rigorous screening. ${ }^{7}$

Based on the background outlined above, the issues to be discussed in the writing of this study are:

- What are the factors that influence juvenile delinquency caused by consuming alcohol?

- How the handling of juvenile delinquency caused by consuming alcohol?

\section{Research Methods}

The type of this research is the kind of empirical juridical. ${ }^{8}$ Empirical juridical law is a research method that seeks to see the law in the real sense or can be said to see, examine how the working of the law in the community, which then uses the research approach, the type of qualitative approach. ${ }^{9}$ A qualitative approach is typically used to produce descriptive data in the form of words written or spoken of persons or observed behavior, and subsequently confirmed by the source of primary data and secondary data sources.

\footnotetext{
${ }^{5}$ Kartini, Kartono, 1997, Patologi Il Kenakalan Remaja, Rajawali, Jakarta, p. 134.

${ }^{6}$ Zakia Darajat, 1973, Perawatan Jiwa untuk Anak-anak, Bulan Bintang, Jakarta, p. 356

${ }^{7}$ Hasan Basri, 1996, Remaja Berkualitas, Problematika remaja dan Solusinya, Pustaka Pelajar, p. 57

${ }^{8}$ See Ulber Silalahi, 2009, Metode Penelitian Sosial, PT. Refika Aditama, Bandung, p. 10.

${ }^{9}$ Lexy J. Moleong, 2006, Metodologi Penelitian Kualitatif, PT. Remaja Rosdakarya, Bandung, p. 26
} 
This research is included in legal research, descriptive-analytical, that describe the legislation in force associated with legal theories and practice of positive law concerning the problem. ${ }^{10}$ Descriptive because in this study is expected to be obtained by thorough and systematic description of the focus of research. While analytically because of the data obtained will be analyzed.

\section{Results And Discussion}

\subsection{Factors That Influence Delinquency Caused Consuming alcohol ${ }^{11}$}

- Curiosity

Motif want to know that teenagers always had nature always wants to know everything that is not yet known or less negative impact. For example, want to know how it feels alcohol, because of busy parents and families with their activities, or as a result of a broken home, lack of affection, then in the event among teenagers trying to find an escape by way of drinking. Facilities and infrastructure, as an expression of affection toward her son and daughter sometimes parents provide facilities and excessive money, but it is abused to satisfy all the desires of adolescent among others originated from drinking alcohol.

- Went along with friends

This factor is closely related to the previous factor if a person of the child who wants to try, also because of the bandwagon, the threat of a friend, and persuasion by friends.

- Milieu

Children who live and hang out in the wrong environment is also very powerful that children consume alcoholic beverages because by associating with people who frequently consume alcohol, it is because children are very quick to adapt to new habits that have never been done.

- Family environment

This factor is closely related to the previous factor if a child received less attention and guidance from his parents indirectly the child will be closer to friends bergaulnya. The boy will be affected consuming alcoholic drinks because of the closeness to her due to lack of knowledge, guidance and messages from parents to not consume alcoholic beverages, which is where the child if often receive guidance and advice from parents to not consume alcoholic beverages will be taken into consideration for the child to not violate the words of their parents. This event happens because of busy parents so much that the time given to his son reduced.

- Sales freely

One thing that can not be denied that the existence of places that provide or sell alcohol such as restaurants, bars, discotics, shops, and karaoke are located around settlement communities that are directly or indirectly by itself adults and teens can afford to find it.

\footnotetext{
${ }^{10}$ Ronny Hanitijo Soemitro, 1988, Metode Penelitian Hukum dan Jurimetri, Ghalia Indonesia; Jakarta, p. 35.

${ }^{11}$ Qibran, Muhammad Khalil. 2014. Tinjauan Kriminologis Terhadap Penyalahgunaan Minum, p. 63- 


\subsection{Handling Juvenile Delinquency Caused Consuming Alcohol}

- Preventive efforts

Preventive measures are the initial efforts made by the police to prevent crime. Attempts were made in the response to preventive is to instill the values / norms are good that these norms internalized in a person. Although there is a chance for committing offenses / crimes but there is no intention to do that then there will be no crime.

- Police work closely with religious leaders to disseminate prevention through a religious approach.

- Police cooperated with the government apparatus that is by putting some police officers in each and every village and village to bring the community with police officers.

- Police provide insight and understanding to the community and especially to the many teenagers who come into contact with problem drinking. By giving the sense that drinking alcoholic beverages is an act that violates the law, and explained about the sanctions that would be acceptable to them whatsoever and howsoever reason.

- Conduct outreach on the dangers of alcohol on health for adolescents and increase the role of parents who are always watching her social life, the implementation of the extension was carried out in schools, universities, and in every village.

- Repressive efforts

Repressive measures, action to suppress and restrain delinquency or impede the onset of delinquency greater events. ${ }^{12}$ This work is done after the occurrence of a crime / crime as a result of drinking. Legal action is intended to provide a deterrent effect to the perpetrators nor the seller of alcohol. According to Kartono, the law action for adolescents who break the law in the form of punishment in accordance with his actions, so it is considered fair and proper functioning conscience can inspire teenagers to live a moral and independent. ${ }^{13}$

For those cases that caused no casualties, the police handed over to families of victims regarding the desired action such as the path of peace or law. Peaceful settlement means the families of the victims to give up what has happened, but if the victim's family may file objections to the police so that the juvenile delinquency cases processed further so that the perpetrators can be given legal sanction or criminal sanctions.

Adolescents who commit a crime, the police can impose legal sanctions based on Act No. 3 of 1997 on Juvenile Court. The law explains the actions that can be performed on children in this case adolescents involved in criminal acts. Police officers carry out actions investigations to prove the guilt or innocence of a teenager in a crime. In Article 18 described any children who are victims or perpetrators of criminal acts are entitled to legal aid and other assistance. If found guilty the next police officer arrests and detentions to be brought to trial. For

\footnotetext{
${ }^{12}$ Gunarsa, Singgih. 1989. Psikologi Remaja. PT BPK Gunung Mulya: Jakarta, p. 140

${ }^{13}$ Kartono, Kartini. 2008. Kenakalan Remaja 2. PT Raja Grafindo Persada: Jakarta, p. 96
} 
teenagers who are convicted of mischief and have permanent legal force subsequently placed in Penitentiary child should be separated from adults. Juvenile delinquency due to alcohol becomes a serious problem because the teenagers of Indonesia is expected in the next generation of future participation. If the bad teenage behavior is certainly liable to bear the burden for the next generation, the nation's ideals of hard to do. Therefore, the police as one of the government agencies participate and perform several steps to achieve maximum results. The first step of preparation needs to be done by the police is to form a part Binamitra (one of strategy in police).

\section{Closing}

\subsection{Conclusion}

- The factors which affecting the growth habit of drinking in teenagers is a curiosity, social environment, family environment, the influence of alcohol sales freely, and as a result of the rule of law (sanctions and fines lightweight).

- Countermeasures drinking habits in teenagers by the police is divided into two stages: a preventive and repressive.

Preventive measures are the initial efforts made by the police to prevent crime. Attempts were made in the response to preventive is to instill the values / norms are good that these norms internalized in a person. Although there is a chance for committing offenses / crimes but there is no intention to do that then there will be no crime. Preventive efforts include socialization, raid the alcohol, and Binamitra, while the repressive measures, action to suppress and restrain juveniles delinquency or impede the onset of delinquency greater events. This work is done after the occurrence of a crime / crime as a result of drinking. Legal action is intended to provide a deterrent effect to the perpetrators nor the seller of alcohol. Repressive efforts include confiscation, arrest, and legal action.

\subsection{Suggestion}

- Crimes committed by juveniles delinquency should not only be underestimated, even though the perpetrator is still classified as a child, but the crimes committed could match the crimes committed adults. Therefore, law enforcement officers should really be able to understand the factors that cause it, so that it can formulate effective measures to prevent cases of juvenile crimes has not increased.

- Other measures should also be conducted by the police in addressing the problem of juvenile delinquency, is to increase the involvement activities dissemination of the crimes as adolescents deviant behavior, either about the dangers, the legal effects and other things for teens to refrain from acts which contrary to the law.

\section{Bibliography}

[1] Desmita. 2010, Psikologi Perkembangan. PT Remaja Rosdakarya, Bandung.

[2] Gunarsa, Singgih. 1989. Psikologi Remaja. PT BPK Gunung Mulya: Jakarta. 
[3] Hasan Basri, 1996, Remaja Berkualitas, Problematika remaja dan Solusinya, Pustaka Pelajar.

[4] Hassan Shadily, 1993, Sosiologi Untuk Masyarakat Indonesia, PT Rinerka Cipta, Jakarta.

[5] Kartini, Kartono, 1997, Patologi II Kenakalan Remaja, Rajawali, Jakarta.

[6] . 2008. Kenakalan Remaja 2. PT Raja Grafindo Persada: Jakarta.

[7] Lexy J. Moleong, 2006, Metodologi Penelitian Kualitatif, PT. Remaja Rosdakarya, Bandung.

[8] Ulber Silalahi, 2009, Metode Penelitian Sosial, PT. Refika Aditama, Bandung.

[9] Qibran, Muhammad Khalil, 2014, Tinjauan Kriminologis Terhadap Penyalahgunaan Minum.

[10] Ronny Hanitijo Soemitro, 1988, Metode Penelitian Hukum dan Jurimetri, Ghalia Indonesia; Jakarta.

[11] Zakia Darajat, 1973, Perawatan Jiwa untuk Anak-anak, Bulan Bintang, Jakarta. 